\title{
Tvorba Pavla Haase v terezínském ghettu (1941-1944)
}

\section{Pavel Haas's Oeuvre in Theresienstadt (1941-1944)}

\author{
Lubomír Spurný / spurny@phil.muni.cz
}

Department of Musicology, Faculty os Arts, Masaryk University, Brno, CZ

\begin{abstract}
Czech composer Pavel Haas (1899-1944) spent his last years in Theresienstadt. He was sent there after the German occupation of the Czech lands in December of 1941. In the first few months, Haas had great difficulty coping with his internment. Long periods of inactivity were punctuated by periods of feverish work, which served to place him among the most active of Theresienstadt composers. Evidence shows that from the second half of 1942 until the fall of 1944, Haas composed seven works, of which three are still extant.

It is generally true that not only in Haas's case does the idea of place enter a work and determine its character. The hectic race against time not only determined the scope and instrumentation of his works, but place also figures prominently in the music's expressivity as well as its fragmentary and unfinished nature. Musical works composed during emotionally charged moments are filled with symbols and allusions of various forms, which express a desire to tell the story of the place. An important aspect of musical activities is also the fact that more than at any other time or place, composers were writing their pieces with specific performers in mind. These performers usually commissioned the works and in many cases were also those who protected the music from destruction.
\end{abstract}

\section{Keywords}

Pavel Haas, Karel Berman, Karel Ančerl, Czech music, contemporary music, autographs, Ghetto Theresienstadt 
Studie, jež se věnuje tvorbě Pavla Haase (1899-1944) během internace v terezínském ghettu, má vztah k připravovanému katalogu díla tohoto autora. ${ }^{1}$ Ve formě doplňujícího komentáře se pokouší zachytit rozptýlené informace vztahující se ke skladatelově tvorbě, aby tak bylo možno vytvořit co možná nejucelenější výpověd' o díle daného období. Zaměřuje se rovněž na kritiku notových autografư a jejich závěry jsou interpretovány s ohledem na autorovo znějící dílo.

Otázky života a díla skladatele Pavla Haase byly zevrubně popsány v řadě textů Lubomíra Peduzziho. Haasův žák, autor monografie Pavel Haas. Život a dílo skladatele (1993) a dlouhé řady studií a článků, které dopodrobna a zasvěceně mapují jednotlivé peripetie Haasova života, dal zájmu o tohoto skladatele jasný směr a díky čilé korespondenci s jeho současníky obohatil bádání o důležité informace. Haasově tvorbě v Terezíně se pak věnují především texty, jež byly později zařazeny do publikace $O$ hudbě v terezínském ghettu. Soubor kritických stati (1999). Peduzziho poměr ke skladateli byl navýsost osobní. Hovořil-li o Haasově působení v Terezíně, vystupuje často se svou výhradní obhajobou Haase proti mladému Gideonu Kleinovi. Jeho výklad je veden snahou vynést Haase jako významnou pozitivní veličinu mezi přední autory domácí meziválečné a válečné hudební kultury. Je důležité tyto motivace znát, není však třeba je odsuzovat. Bylo by možné podobný úkaz chápat jako svědectví o době, která napravuje staré křivdy, nebot obhájcům „nedoceněných autorů “ záleží na tom, aby bylo jejich dílu rozuměno, a jsou ochotni svádět o ně vášnivé polemiky.

Mezi muzikology, kteří se v nedávné době poučeně vyjadřovali k hudbě v terezínském ghettu a v dílčích sondách rovněž k dílu Pavla Haase, zaujímá čelní místo Milan Kuna. Jestliže Peduzzi věnuje svou pozornost především Haasovi a ostatní dění shrnuje jen do letmých a výběrových informací, vyznačuje se Kunův přístup snahou postihnout terezínskou hudební tradici v širším kontextu. Pro mnoho autorů pak byla významnou inspirací kniha Joži Karase (1926-2008) Music in Terezin: 1941-1945 (1985). Karas využil k popisu jednotlivých důležitých událostí četná svědectví a prameny, které nebyly do té doby běžně $\mathrm{k}$ dispozici. I když se na řadě míst setkáváme s nepřesnostmi či neurčitými odkazy, stále platí, že tuto knihu můžeme považovat za relevantní pomůcku k orientaci v dějinách hudby v terezínském ghettu. V této souvislosti rovněž stojí za zmínku, že prozatím nezpracovaná pozůstalost Joži Karase je uložena ve Sbírkovém oddělení Památníku Terezín.

Především zahraničním čtenářům je určena memoárová publikace Terezin (1965). Ve vzpomínkách bývalých vězňů je zachyceno rovněž hudební dění a osudy jejich protagonistů. V kapitolách věnovaných hudbě nalezneme př́íspěvky Norberta Frýda, Jany Šedové, Arnošta Weisse, Karla Bermana, Karla Ančerla, Trudy Solarové, Rudolfa Fraňka ad. Jejich cenné vzpomínky nabídly proměnlivé průhledy do dění v Terezíně. Mozaika prožitých příběhů si na druhé straně nečiní nárok na věcnou přesnost. Autoři knihy nezamýšleli lidské příběhy korigovat či doplňovat novými jmény či daty. Marně bychom zde proto hledali jasnější zmínky o Bernardu Kaffovi, Zikmundu (Siegmundu) Schulovi,

1 Předložená studie vznikla v rámci projektu „Pavel Haas. Katalog díla“ za finanční podpory Grantové agentury České republiky (registrační číslo grantového projektu 18-05356S). Katalog vzniká ve spolupráci s Ondřejem Pivodou. 
Carlo Taubemu či Viktoru Ullmannovi. I když tyto zdánlivé nedostatky později vyvolaly nevoli u některých recenzentů, není kritické čtení na místě, vždyt’ osobní vzpomínky jsou nutně selektivní a vybírají z paměti pouze to, co je pro jejich aktéry smysluplné a zapamatovatelné.

Neocenitelným pomocníkem při zkoumání kulturního života v Terezíně je tzv. Heřmanova sbirka. Tento rozsáhlý soubor dokumentů, vztahujících se ke společenskému životu v ghettu, shromažd'oval terezínský vězeň Karel Herrmann (Heřman)² od roku 1943 do září 1944. Jedním z muzikologicky nejcennějších dokladů o hudebním životě v ghettu jsou pak recenze Viktora Ullmanna 26 Kritiken über musikalische Veranstaltungen in Theresienstadt (1993). Jejich vydání opatřil komentářem a úvodní studií Ingo Schultz.

Snad nejdůležitějším dokladem Haasovy činnosti v Terezíně jsou notované autografy. Tři skladby z terezínského období se dochovaly díky velké porci štěstí. Rukopisný materiál zachovaných skladeb nalezneme v Oddělení dějin hudby Moravského zemského muzea v Brně, v Židovském muzeu v Praze a ve Sbírkovém oddělení Památníku Terezín.

$$
* * *
$$

V drobné studii Why Study the Music of Terezin?, uveřejněné na stránkách Institutu terezínských skladatelů (The Terezín Composers‘ Institute), zmiňuje Michael Beckerman možné vazby mezi dílem a místem jeho vzniku. Odkaz na topografii je v tomto případě mimořádně významný. Jako renomovaný muzikolog, organizátor či interpret má bezpochyby osobní zkušenosti nejen se živým prováděním terezínských skladeb, ale i s lidmi, kteří se do této hudby hluboce noří, aby se nechali unášet hudebními citacemi či zpozorněli při přesvědčivé interpretaci, či, poeticky řečeno, aby pronikali do duše díla. Program „Terezín“ tak skladbám, jež by byly běžně pojímány jako součást hudby určité doby a poetiky, dodává zvláštní emocionální hodnotu.

Již samo označení terezínská hudba obsahuje jistou klasifikaci. V historických etapách poválečného vývoje bylo toto téma mnohokrát připomínáno, pokaždé v jiném kontextu a odlišných konotacích. Naše představy o kulturních aktivitách v terezínském ghettu prošly za tuto dobu jistými peripetiemi a s trochou nadsázky můžeme říct, že tato historie dnes žije životy těch, kteří přežili. Naše znalosti o hudbě v Terezíně se skládají z útržků vzpomínek a z dochovaných dokumentů, které již v době svého vzniku byly často nepřesné, neúplné, protichůdné. Ztracené autografy, některé z nich po letech znovu nalezené, pak tuto mozaiku problémů doplňují o otázky kompozičních kvalit skladeb, jejich zesílených emocionálních obsahů či možností zasazení do kontextu domácí a středoevropské hudby.

Viktor Ullmann, Pavel Haas, Hans Krása, Gideon Klein, Zikmund Schul, Hans Winterberg či Karel Reiner patří mezi skladatele střední a mladší generace, jež se svou tvorbou zařadili do poetiky moderních směrů 20. století. Až na tuto okolnost a společný židovský původ se zdá být jejich spojení nahodilé. Skupina, označovaná jako terezínští

2 Karel Herrmann (1905-1953) si v roce 1946 nechal změnit jméno na Heřman. Ještě před deportací do Osvětimi v říjnu 1944 se mu podařilo uschovat cenný dokument u jedné ze spoluvězenkyň. Heřmanova manželka prodala na počátku 70. let většinu listů z Heřmanozy sbirky Památníku Terezín. 
skladatelé není a snad ani nechtěla být prototypem kompoziční školy. Jmenovaní skladatelé nevyznávali společnou etiku a poetiku tvưrčí práce, nevyužívali obdobné kompoziční postupy a nebyli sdruženi pod patronací výrazné tvưrčí osobnosti. Jejich terezínské skladby mají velmi málo společného s verzí inovativní tvorby překonávající zastaralé metody či šokující svou neotřelostí. Neukrývají v sobě snahu po diferencování uměleckých postupů a od jejich tvůrců nelze očekávat snahu po nalézání neopotřebovaných forem či žánrových kombinací.

Označení terezinšti skladatelé má přesto své opodstatnění. Téma místa prostupuje tvorbou a určuje charakter děl. Do jejich ustrojení promlouvají ryze praktické důvody určované životní situací, ve které se každý ze skladatelů v danou chvíli nacházel. Jsme účastni situace, kdy se komponování stává skrytým zápasem o přežití.

Po celou dobu existence ghetta byl běžný život poznamenán hmotným nedostatkem a trvalým psychickým strádáním prostoupeným každodenní obavou ze zařazení do transportu na východ. Klid na tvưrčí práci prakticky neexistoval. Také nemožnost přehrávat si rozpracované skladby na klavír přinášel významná omezení. Bez předchozí zkušenosti, bez tradice minulých děl a jasných představ o výsledném znějícím tvaru by patrně terezínská produkce směřovala k banalitám. Hektický závod s časem určoval nejen rozsah a obsazení, ale svůj výraz nalezl také v expresivitě a fragmentárnosti skladeb. Hudební díla komponována v emocionálně vypjatých chvílích jsou prostoupena systémem znaků a citací různé úrovně, vyjevujících touhu vyprávět tragický př́iběh a nesklouznout při tom ke kýči. Obsahy terezínských děl jsou pak latentně ukryty pod povrchem, daleko skrytěji, než tomu běžně bývá. Důležitým momentem hudebního provozu je rovněž fakt, že osudy svých děl více než kdy jindy skladatelé spojovali s vybranými interprety. Ti byli většinou prvními zadavateli a v řadě případi̊ také těmi, jež autograf uchránili před zničením.

Autentickou zprávou o podmínkách v terezínském ghettu je esej Viktora Ullmanna Goethe und Ghetto (1944):

„Theresienstadt war und ist für mich Schule der Form. Früher, wo man Wucht und Last des stofflichen Lebens nicht fühlte, weil der Komfort, diese magie der Zivilisation, sie verdrängte, war es leicht, die schöne Form zu schaffen. Hier, wo man auch im täglichen Leben den Stoff durch die Form zu überwinden hat, wo alles Musische in vollem Gegensatz zur Umwel vertilgent steht: Hier ist die wahre Meisterschule, wenn man mit Schiller das Geheimnis des Kunstewrks darin sieht: den Stoff durch die Form zu vertilgen - was ja vermutlich die die Mission des Menschen überhaupt ist, nicht nur des aesthetischen, sondern auch des ethischen Menschen. [...] Auch der empfindliche Mangel an Notenpapier dürfte für kommende Geschlechter uninteressant sein. Zu betonen ist nur, dass ich in meiner musikalischen Arbeit durch Theresienstadt gefördert und mein etwa gehemmt worden bin, dass wir keineswegs bloss klagend an Babylons Flüssen sassen und dass unser Kulturwille unserem Lebenswillen adäquat war; und ich bin überzeugt davon, dass alle, die bestrebt waren, in Leben und Kunst die Form dem wiederstrebenden Stoffe abzubringen, mir Recht geben werden."3

3 SCHULTZ, Ingo (ed.). Viktor Ullmann. 26 Kritiken über musikalische Veranstaltungen in Theresienstadt, mit einem Geleitwort von Thomas Mandl. Neumünster: Bockel Verlag, 2011, s. 110-111. 
Ullmannův text psaný formou jasného úsporného vyjádření, vznikl pravděpodobně na sklonku léta 1944. Lze se jen dohadovat, jak na autora zapůsobily zprávy o vylodění spojeneckých vojsk v Normandii, atentátu na Hitlera či o postupu Rudé armády na východě. Pro život v ghettu měly tyto události zcela opačný efekt. Strach z blížící se fronty a snaha dokončit plán konečného řešení židovské otázky uspíšila transporty na východ. ${ }^{4}$

$$
* * *
$$

Zaměříme-li svou pozornost na Pavla Haase, objeví se obraz autora, jenž se v prvních měsících pobytu v ghettu těžko vyrovnával s novou situací. Dlouhodobá nečinnost ovšem byla po mnoha měsících vystřídána horečnou prací, která jej zařadila mezi nejaktivnější terezínské skladatele.

Haas byl deportován do Terezína jedním z prvních transportů počátkem prosince 1941, ${ }^{5}$ na podzim 1942 pak zkomponoval svou první skladbu, mužský sbor Al s’ fod. Prosté konstatování těchto dvou událostí ovšem nevystihuje dramatičnost situace. Přestože o osudech skladby, o její premiéře a prvních interpretech nevíme prakticky nic, je bezpochyby životopisně spolehlivým obrazem toho, co terezínské společenství prožívalo.

Motivace vzniku $A l$ s' fod bývají připisovány mladému Gideonu Kleinovi. Důležité svědectví uvádí Joža Karas v knize Music in Terezin:

„[Gideon Klein] could not reconcile himself to seeing an artist of Haas'caliber not participating in the musical activities. So, on day, to wake him from his letargy, Klein put in front of him several sheets of manuscript paper, on which he himself drew the musical staff, and urged Haas to stop wasting time. "6

K umocnění této stylizace přispívá text sboru $A l$ s' fod svým jasným poselstvím: „Nenařikej, neplač, když je zle, nevěs hlavu, pracuj, pracuj!“ Přesto, že je tento obraz náležitě upraven, navzdory odmítnutí Lubomíra Peduzziho, zapadá Kleinovo gesto vcelku věrohodně do sledu událostí.

Pro svůj sbor zvolil Haas hebrejský text básně izraelského básníka, spisovatele a překladatele Davida Shimoniho. ${ }^{7}$ Báseň nabádající k vytrvalosti a odvaze bezprostředně reaguje na nepokoje, které v letech 1928-1929 vypukly mezi židovským obyvatelstvem a palestinskými Araby na území tehdejší Palestiny. ${ }^{8}$ Skladatel patrně neuměl hebrejsky, proto si za vzor deklamace zvolil píseň Josepha Milleta (1889-1947), složenou na stejný

4 Plán konečného řešení židovské otázky byl navržen 20. ledna 1942 na jednání ve Wannsee. Schůzi, které se účastnili nejvyšší představitelé nacistického Německa, předsedal Reinhard Heydrich.

5 Pavel Haas do Terezína odjíždí z Brna 2. prosince 1941 (transport G, č. 731) První transport tzv. Aufbaukomando (komando výstavby) odjelo z Prahy do Terezína již 24. listopadu 1941.

6 KARAS, Joža. Music in Terezín 1941-1945. New York: Beaufort Books Publishers, 2002, s. 61.

7 David Shimoni (Shimonovitz, 25. 8. 1886 - 10. 12. 1956), izraelský básník, spisovatel a překladatel běloruského původu.

8 Výsledkem bojů byla tzv. Passfieldova Bílá kniha (The Passfield White Paper) požadující prosazení kvóty pro židovské přistěhovalce. Odsuzovala dvě hlavní židovské organizace (odborový svaz Histadrut a Jewish Agency for Israel), které podporovaly pouze židovskou zaměstnanost. Protesty sionostů i podpora významných britských osobností nakonec rozhodnutí britské vlády zmírnily. 
text. Podle tvrzení Lubomíra Peduzziho se Milletovy písně v ghettu zpívaly. ${ }^{9}$ Haas skladbu dokončil 30. listopadu 1942 a věnoval ji Otto Zuckerovi (1892-1944), členovi samosprávy ghetta, zástupci židovského staršího Jakoba Edelsteina (1903-1944). ${ }^{10} \mathrm{~V}$ notách stylizovaný hebrejský kryptogram na titulní straně autografu rovněž uvádí, že skladba připomíná první rok terezínské internace: „Vzpomínka na proni a zároveň posledni výroči terezinského vyhnanstvi."

Fotokopie rukopisu sboru je dnes uložena v Židovském muzeu v Praze. ${ }^{11}$ Je součástí nevelkého konvolutu, jež obsahuje autografy a opisy děl některých skladeb, které během války zazněly v ghettu Theresienstadt. Způsob zařazení kopie autografu bohužel nedovoluje identifikovat zpo̊sob, jakým se zápis do Židovského muzea dostal.

O provedení díla neexistuje žádný záznam, lze ovšem předpokládat, že skladba byla určena pro první terezínský mužský sbor vedený Rafaelem Schächterem (1905-1945). ${ }^{12}$ Jeho aktivním pomocníkem byl rovněž Klein. Zprávy o jeho působení v ghettu potvrzují, že se v této době věnoval sborovým úpravám lidových písní, především českých a slezských, ale také židovských a ruských. Poté se pustil ke komponování skladeb vlastních. ${ }^{13}$ Na rozdíl od něj si Pavel Haas zachovával k tomuto typu tvorby střízlivý odstup. Volba úderného a proklamativního textu Haasova terezínského sboru kontrastuje s jeho následující tvorbou.

$$
* * *
$$

V druhé polovině roku 1943 Haas dokončil Studii pro smyčcový orchestr; podle zasvěceného odhadu Lubomíra Peduzziho na ní pracoval od jara do podzimu 1943. Datace je v tomto případě pouze orientační. Nedochovaný autograf díla či jiné Haasovy doklady o práci na díle nám neumožňují přesnější určení. Peduzziho načasování má několik důvodů. Ten hlavní se vztahuje k založení a působení smyčcového orchestru Karla Ančerla (1908-1973), který do ghetta nastoupil v listopadu 1942 a již v polovině následujícího roku měl k dispozici vlastní smyčcový orchestr. O jeho činnosti se vedle ústních svědectví dovídáme z Ullmannovy terezínské kritiky č. $14 .{ }^{14}$

9 PEDUZZI, Lubomír, Pavel Haas: Život a dílo skladatele. Brno: Muzejní a vlastivědná společnost v Brně, 1993, s. 110.

10 Nejedná se o jedinou dedikaci Otto Zuckerovi. Viktor Kohn je autorem skladby Praeludium EDElstein, jež je dedikována společně Jakobu Edelsteinovi a Zuckerovi. Dle poznámky v autografu byla skladba dokončena 4. 12. 1942.

11 Židovské muzeum v Praze (dále jen JMP), inv. č. 319a.

12 Dirigent, klavírista a skladatel Rafael Schächter byl jednou z vůdčích postav hudebního života v Terezíně. Jím vedený sbor měl na počátku své existence okolo dvaceti členů. Viz KUNA, Milan. Hudba vzdoru a naděje: Terezín 1941-1945. Praha: Editio Bärenreiter Praha, 2000, s. 24. První z řady oper, které Schächterův soubor provedl, byla Smetanova Prodaná nevěsta (prem. 25. 11. 1942). Schächter v Terezíně nastudoval rovněž Verdiho Rekviem (prem. před 6. 9. 1943).

13 V té době Klein zkomponoval Madrigal pro dva soprány, alt, tenor a bas na slova Francoise Villona (1942), Pruni hřich, mužský sbor na slova české lidové poezie (1942) a Madrigal pro dva soprány, alt, tenor a bas na slova Friedricha Hölderlina (1943).

14 Srov. SCHULTZ, op. cit., s. 81-83. 
Při uvedení Haasovy skladby hrálo v orchestru odhadem 30 hudebníků, což vyplývá z dochovaného záznamu koncertu ve filmu Theresienstadt (1945). I když není záběr vždy zřetelný, má významnou dokumentární hodnotu. Za připomínku stojí, že ve filmu se v záběru objeví také děkující Pavel Haas. Podle záznamů v původních opisech partů, na základě svědectví přeživších hudebníků a s pomocí zmiňované filmové pasáže uvádí Lubomír Peduzzi svůj odhad a některé členy představuje jmenovitě: koncertní mistr Egon Ledeč; vn I: (?) Tomáš Mandl, Pavel Kling; vn II: Aurel Flax, Ilona Králová (Král); vla: Otto (?) Parkus; vcl: (?) Klapp, (?) Schwaab; cb: Elisabeth Bärlein. ${ }^{15}$

Podle zmíněné Ullmannovy kritiky č. 14 se premiéra díla uskutečnila 13. září 1944 (II. Konzert des Ančerl-Orchesters, 13. September 44, Bühnensaal). Autor v ní oceňuje zajímavý polyrytmický úvod skladby směřující k energické fugové expozici, za nedostatečné považuje obsazení kontrabasư. ${ }^{16}$ Zbývá jen dodat, že informace o místě a době konání se v Ullmannových kritikách běžně nevyskytují; žádná další takové sdělení neobsahuje. Podle názoru Ingo Schulze je tento detail záměrný, má připomenout 70. narozeniny Arnolda Schönberga, Ullmannova přítele a mentora. Také u jiných autorů nacházíme zmínky o uvedení skladby. Willi Mahler v deníkových zápiscích například přináší informaci o tom, že Studie byla hrána 16. září 1944 před přednáškou dr. Paula Eppsteina v tzv. Speisehalle. Dochovaný týdenní přehled koncertů konaných mezi 25. zářím a 1. říjnem 1944 z Heřmanozy sbirky zaznamenává koncert Ančerlova orchestru s Haasovou skladbou ještě v sobotu 30. září 1944.

Kvưli natáčení jedné ze sekvencí do propagandistického filmu Theresienstadt. Ein Dokumentarfilm aus dem jüdischen Siedlungsgebiet zazněla část skladby 1. září 1944; film je dnes spíše známý pod neoficiálním názvem Der Führer schenkt den Juden eine Stadt (Vi̊dce daroval [daruje] Židům město). Autory filmu byli terezínský vězeň, německý herec a režisér Kurt Gerron (1897-1944) a český filmový producent Karel Pečený (1899-1965). Natáčení probíhalo od 16. srpna do 11. září 1944 a k jeho dokončení došlo 28. března 1945. Bezprostředně po premiéře měl být film zničen, přesto se jeho fragmenty v několika archivech zachovaly. Karel Ančerl k okolnostem př́ípravy filmu poznamenal:

\begin{abstract}
"When we had finished rehearsing this program, orders came to hold the concert in the hall of the so-called café. Surprised, knowing that no good could come of it, we were let into the flower-decorated hall. We were all issued black suits, my conductor's stand was lined with flowers to hide my clogs. Soon a high official visitor in SS-uniform appeared to inspect if everything was going all right. Czech Quislings with film cameras appeared. I was told to introduce the composer Paul Haas after the first performance of his music to the invisible, cheering audience. This farce was filmed to show the world outside the ideal conditions of our ghetto life. The following day [sic!] the normal concert of our second program took place
\end{abstract}

15 PEDUZZI, Lubomír. Pavel Haas: Život a dílo skladatele, op. cit., s. 101-102.

16 V recenzi Ullmann píše: „Die Studie ist ganz aus dem Wesen des Streichorchesters geholt und klingt gut: sie ist weniger revolutionär als Haas" früher hier entworfene Werke. Im Ganzen zeigt sie die Hand eines Musikers, der weiss, was er will und es auch kann. Die Leistung des Orchesters war - bis auf den Mangel an Contrabässen - durchaus befriedigend." Srov. SCHULTZ, op. cit., s. 82. 
and two days later, in October 1944 [sic!], all of us, together woth 2,500 other ghetto inmates, were sent in a transport to Auschwitz."17

Při záchraně skladby sehrál roli souběh štastných událostí. Haasův autograf se sice nedochoval, Ančerlovi se však po válce podařilo shromáždit opisy všech partů, s výjimkou kontrabasového. Lubomír Peduzzi tento part dokomponoval a v roce 1959 vyhotovil opis partitury skladby. ${ }^{18}$

$$
* * *
$$

S ohledem na fungování židovské samosprávy nazval Hans Günther Adler období od léta 1943 do podzimu 1944 „židovským sdileným územím“. Jeho trvání se z velké části krylo se zkrášlovací akcí (Stadtverschönerung). Město mělo být připraveno na návštěvu komise Mezinárodního Červeného kříže, aby jako „vzorové židovské sídliště“ mohl před světovou veřejností vylepšit obraz nacistického Německa. (Vzpomínaná návštěva se uskutečnila 23. 6. 1944.) „Terezín už neměl být ghettem, nýbrž židovským sídlištěm, v němž Židé žiji sice odloučeně, ale nicméně spokojeně pod vlastni samosprávou; idyla uprostřed válečných hrůz, během nichž se německému civilnímu obyvatelstvu, [...] daři podstatně hůr̆ než Židưm pod zvláštni ochranou Adolfa Hitlera, který si zjevně vytýčil úkol být jejich zachráncem i ochranitelem před spravedlivým hněvem německého lidu. "19 Během tohoto poměrně klidného období Haas dokončil písňový cyklus pro bas (baryton) a klavír Čtyři písně na slova čínské poesie. Přestože v autografu díla nalezneme znění Písně na slova čínské poezie, uvádí terezínský plakát název 4 pisně na slova činské poesie. ${ }^{20}$ Tato drobná nuance měla patrně odlišit skladatelův cyklus Činské pisně, op. 4 pro alt a klavír z roku 1921 od nově vzniklého díla. Lubomír Peduzzi navrhoval uvést skladbu pod titulem „Domov je tam“ podle textu úvodní písně (Zaslech jsem divoké husy...), to se ale v praxi neujalo a dnes dílo známe jako Čtyři pisně na slova činské poezie, či zkráceně Čtyři písně. Záznamy v autografu uvádějí dokončení každé písně zvlášt. Údaje nám pak umožní udělat si jasnější představu o časových možnostech terezínských vězňů v tomto relativně klidném období: Zaslech jsem divoké husy (24. 2. 1944), V bambusovém háji (7. 3. 1944), Daleko měsíc je domova (6. 4. 1944), Probdèná noc (27. 4. 1944).

Podle programového listu z Heřmanozy sbirky se premiéra uskutečnila 22. června 1944 v sále bývalé radnice. ${ }^{21}$ Dílo bylo zařazeno do programu recitálu Karla Bermana za kla-

17 ANČERL, Karel. Music in Terezín. In EHERMANN, František - HEITLINGER, Otta - ILTIS, Rudolf (eds.). Terezín: 1941-1945. Praha: Židovská náboženská obec v Praze, 1965, s. 240. Ančerl má patrně na mysli transport z 28. září 1944 (2 499 vězňủ). Spolu s manželkou a synem byl ovšem zařazen do ř́ijnového transportu (Er, 16. ř́jjna 1944, 1500 vězňů). V tomto transportu byli rovněž Pavel Haas, Gideon Klein, Bernard Kaff, Hans Krása, Rafael Schächter, Viktor Ullmann.

18 Oddělení dějin hudby Moravského zemského muzea (dále jen ODH MZM), sign. A 54.253.

19 ADLER, Hans Günther. Terezin 1941-1945. Tuář nuceného společenství. I. Dějiny. Praha: Barrister \& Principal, 2003, s. 5 .

20 Autograf díla je uložen v Databázi sbírek sbírkového oddělení Památníku Terezín, inv. č. 13025.

Plakát je součástí Heřmanovy sbírky; viz Databáze sbírek sbírkového oddělení Památníku Terezín, inv. č. 4288.

21 Joža Karas datuje premiéru na květen 1944 (Viz KARAS, op. cit. s. 67.) Zdroj informace autor neuvádí. 
vírního doprovodu Rafaela Schächtera. Skvělého hodnocení se dostalo skladateli i umělcům v Ullmannově kritice č. 15 (Liederabend Karl Bermann). ${ }^{22}$ Berman byl nejen prvním interpretem, ale rovněž iniciátorem a zachráncem skladby. ${ }^{23}$ Po letech k tomu dodává:

„Bylo to někdy v roce 1943, kdy jsem s dirigentem Schächterem domlouval program pisňového koncertu. Rozhodli jsme se zařadit tři pisně Schubertovy a Dvorákovy Cikánské melodie a po přestávce Beethovenưv cyklus Vzdálené milé. Nenašli jsme však žádné srozumitelné, jinotajné zakončeni, které se mělo stát vrcholem koncertu, otresnou obhajobou př́tomnosti. Vycházeli jsme z naši sklepni zkušebny v L 40 a na druhé straně chodniku šel pianista Bernard Kaff se skladatelem Pavlem Haasem. Slovo dalo slovo, prosba, vysvětlení, oč v koncertu jde. Haas vzpomíná, že má náramné texty, že právě čte Mathesia, že neslibuje, ale že se pokusi. “24

$$
* * *
$$

Nedlouho po natáčení filmu Theresienstadt byly zahájeny hromadné transporty do vyhlazovacího tábora v Osvětimi. V období od 28. září do 28. října 1944 bylo odesláno celkem 11 transportů s 18.400 vězni, z nichž přežilo pouze 1.574 osob. Pavel Haas k nim nepatřil. Bezprostředně po příjezdu do vyhlazovacího tábora 18. ř́íjna 1944 byl z železniční rampy jako práce neschopný odeslán spolu s ostatními do plynové komory.

O dalších Haasových skladbách se dovídáme již jen zprostředkovaně. Bezprostředně před odchodem do transportu nezůstal v Terezíně nikdo, u koho by své skladby mohl zanechat, proto se lze domnívat, že je vzal s sebou do transportu.

Kromě marginálních poznámek na okraji kreseb a upomínkových listů jsou nejčastějším zdrojem informací svědectví terezínských vězňů. Až na jednu z Ullmannových recenzí platí, že drobné odkazy nic bližšího nesdělují a při dalším kritickém prozkoumání vykazují mnohé nepřesnosti. V tomto ohledu není výjimkou ani seznam Haasových terezínských skladeb z dopisu Tomáše Mandla adresovaném Lubomíru Peduzzimu v roce 1949..$^{25}$ Autor dopisu poznamenává, že se jedná pouze o přibližné informace:

S největší pravděpodobností ji získal od Karla Bermana. Na programu byly následující skladby: Hugo Wolf: Michelangelo Lieder; Ludwig van Beethoven: Auf die ferne Geliebte; Pavel Haas: Čtyri písně na slova činské poezie; Antonín Dvořák: Cikánské melodie.

22 SCHULTZ, op. cit., s. 83-85.

23 Na první straně autografu v záhlaví můžeme rovněž číst tuto dedikaci: „Pronímu interpretu, milému p. K. Bermannovi v upomínku na pĩvodni premieru Pavel Haas.“ Autograf díla je dnes uložen ve Sbírkovém oddělení Památníku Terezín. V autografu je ještě uvedena původní verze Bermanova jména. Ten po válce používal pouze jeho počeštěnou podobu s jedním „n“. Před transportem do Osvětimi předal Berman autograf své známé N. Schwarzové. (Srov. PEDUZZI, Lubomír, Pavel Haas: Život a dílo skladatele, op. cit. s. 111.) Po Bermanově smrti (1995) darovala jeho žena Christina Bermanová autograf Památníku Terezín (17. 3. 1997). Téhož roku autograf restauroval Miroslav Široký. V Židovském muzeu v Praze je uložena kopie první strany tohoto autografu (JMP, inv. č. 319a/002.)

24 BERMAN, Karel. Vzpomínka, rukopis v pozůstalosti autora, s. 86. Srov. SEDLÁČKOVÁ, Pavlína. Čtyři písně na slova činské poezie: Výpověd’ terezinského vězně. Bakalářská diplomová práce. Brno: Masarykova univerzita, Filozofická fakulta, 2011, s. 21.

25 Jako součást prozatím nezpracované pozůstalosti Lubomíra Peduzziho. (ODH MZM, přír. č. 5/2009). 
Cyklus pisni (1942)

Smyčcový kvartet (IV.) [připsáno rukou] Ledečovo kvarteto

Studie pro smyčc. orchestr (1943)

Kvartetni věta na žid. téma [připsáno rukou] Ledečovo kvarteto

3 pisněs dech. kvintetem

Písně na slova činské poezie

Variace pro klavir a smyčc.orchestr (1944)

Rekviem

Jednu z prvních zmínek o Haasových nedochovaných skladbách zaznamenal Bohumír Štědroň v předmluvě vydání Haasových Čtyř písni na slova činské poezie. ${ }^{26} \mathrm{~S}$ odkazem na svědectví Karla Ančerla zmiňuje cyklus tří skladeb pro mezzosoprán, tenor, flétnu, klarinet a smyčcový kvartet na slova Františka Halase [sic!] nazvaný Advent. Po mnoha letech Lubomír Peduzzi zpochybnil spolu s obsazením skladby také autora textu. ${ }^{27}$

Pro Ančerlův smyčcový orchestr a klavíristu Bernarda Kaffa připravoval Haas někdy v průběhu roku 1943 Variace pro klavír a smyčcový orchestr. Stupeň rozpracování skladby neznáme. Jediným dokladem o její existenci je Haasův přípis pod portrét (kresba tužkou) od terezínského malíre Maxe Placzka (1902-1944) datovaný 24. října 1943. Přípis obsahuje čtyři takty s komentářem: „quasi uspávanka z variací pro klav. a orchestr". ${ }^{28}$

Joža Karas ve své terezínské monografii zmiňuje Haasův záměr komponovat v roce 1944 Requiem (Requiem pro sóla, sbor a orchestr). Tento pokus pravděpodobně zůstal ve stádiu přípravných skic. (Rekviem/Requiem se objeví rovněž na Mandlově seznamu.)

28. června 1944 hrál na koncertě Bernard Kaff Partitu ve starém slohu. Toto sdělení spolu s autografním zápisem prvních pěti taktů šesté části (Gigue) objevíme na upomínkovém listě věnovaném Karlu Herrmannovi (Heřmanovi). ${ }^{29} \mathrm{Na}$ rozdíl od ostatních nedochovaných skladeb její existenci potvrzuje recenze č. 8 Viktora Ullmanna:

„Bernard Kaff spielte mutig ein modernes Programm. Eigentlich wird die neuere Musik nur um ihrer Harmonik willen gefürchtet, denn mit ganz geringen Ausnahmen ist ja die klassische Form nicht preisgegeben worden. Das Aufgehen des tonalen Systems, also der naturgegebenen Obertöne, einsprach dem Verlassen der getreuen Naturnachahmung in der Malerei. Paul Haas setzte aber diesen Prozess nicht fort, er führt eigentlich umgekehrt die neuen Klänge in die Tonalität ein. Man könnte von einer tonalen Zwölftonmusik sprechen. 'Die Partita im alten Stil' wahr die Formen oder wenigsten die Urphänomene der Suitensätze. Haas Musik ist auch hier durchaus zu bejahen, sie ist spielend-kraftvoll, ungezwungen mehrstimmig, durchsichtig im Klaviersatz, interessant und graziös. Ich gebe der kleinen Air den Preis, ohne darum die anderen Suitensätze

26 Předmluva Bohumíra Štědroně k vydání Čtyř písni na slova č́nské poesie. Brno: Rovnost, 1948.

27 Podle Peduzziho zjištění by se mohlo jednat o text básníka a novináře Karla Tomana (1877-1946). Srov. PEDUZZI, Lubomír. O hudbě v terezinském ghettu. Soubor kritických statí. Brno: Barrister \& Principal, 1999, s. $61-62$.

28 Kresba je uložena v Židovském muzeu v Praze (JMP), inv. č. 170.826.

29 Upomínkový list obsahuje tento zápis, jenž je datován 1. 9. 1944: „Začátek 6. věty z „Partity ve starém slohu“ pro klavír, věnováno B. Kaffovi, který ji poprvé provedl 28. VI. 1944 v Terezine.." Viz Databáze sbírek sbírkového oddělení Památníku Terezín, inv. č. 3914. 
herabsetzen zu wollen. Ob der Ausdruck 'Partita' für die tonal-schwebende und in den einzelnen Sätzen verschiedene Stücke noch angewendet werden soll, ist eine Frage für sich. In der Partita sind ursprünglich alle Sätze durch die gleiche Tonart verbunden. Ich hätte daher die Bezeichnung als 2. Suite vorgezogen. "30

Haasova tvorba posledních let zmizela v minulosti. V podobných případech platí, že dílo může následovat osudy svých tvůrců a interpretů. Přes tuto nejistotu umožňují dochované prameny alespoň přibližně rekonstruovat chronologii Haasovy závěrečné tvorby:

Al s’ fod (30. 11. 1942); mužský sbor (TTBB)

Studie pro smyčcový orchestr (jaro - podzim 1943); prem. 13. září 1944, smyčcový orchestr pod vedením Karla Ančerla

Variace pro klavír a smyčcový orchestr (1943)

Fantazie na židovskou národni píseñ pro smyčcové kvarteto (1943); prem. Ledečovo kvarteto, 1943-1944

Advent (?1944); [? 3 písně s dechovým kvintetem]

Čtyři písně na slova činské poesie (24. 2. - 27. 4. 1944); prem. 22. 6. 1944, Karel Berman (B), Rafael Schächter (pf)

Partita ve starém slohu (1944); prem. Bernard Kaff, 28. 6. 1944

Requiem pro sóla, sbor a orchestr (?1944)

\section{Bibliography}

ADLER, Hans Günther. Terezín 1941-1945. Tvář nuceného společenství. I. Dějiny. Praha: Barrister \& Principal, 2003.

ANČERL, Karel. Music in Terezín. In EHERMANN, František - HEITLINGER, Otta - ILTIS, Rudolf (eds.). Terezin: 1941-1945. Praha: Židovská náboženská obec v Praze, 1965, s. 238-241.

BECKERMAN, Michael. Why Study the Music of Terezín? The Terezin Composers' Institute, Newsletter, 29 (2018), no. 2, 31-40. Dostupné z: http://terezincomposersinstitute.com/wp-content/ uploads/2018/09/Newsletter_02_08_18_EN-3.pdf

BERMAN, Karel. Vzpomínka na skladatele Pavla Haase. Hudebni rozhledy, roč. 8, 1955, č. 5, s. 235.

BERMAN, Karel. Před 25 lety zahynul Pavel Haas. Věstnik židovských náboženských obci v Československu, roč. 31, 1969, č. 10, s. 6 .

KARAS, Joža. Music in Terezín 1941-1945. New York: Beaufort Books Publishers, 2002.

KARBUSICKÝ, Vladimír. Exotismus životní absurdity. Pavla Haase Čtyři písně na slova čínské poezie. Hudebni věda, roč. 34, 1997, č. 2, s. 147-169.

KARBUSICKÝ, Vladimír. Neukončená historie. Hudebni věda, roč. 35,1998, č. 4, s. 396-405.

30 SCHULTZ, op. cit., s. 68-69. Na programu koncertu pak zazněly následující skladby: Pavel Haas: Partita ve starém slohu; Leoš Janáček: $V$ mlhách; Modest Petrovič Musorgskij: Obrázky z výstary. 
KUNA, Milan. Hudba v koncentračních táborech. Terezín: Památník Terezín, 1982.

KUNA, Milan. Hudba na hranici života: O činnosti a utrpeni hudebniki z čes. zemi v nacistických koncentračnich táborech a věznicich. Praha: Naše vojsko, 1990.

KUNA, Milan. Hudba vzdoru a naděje: Terezín 1941-1945. Praha: Editio Bärenreiter Praha, 2000.

PEDUZZI, Lubomír. Vlastenecká symbolika posledních děl Pavla Haase. Sbornik Janáčkovy akademie múzických uměni, 3, 1961, s. 75-97.

PEDUZZI, Lubomír. Složeno v Terezíně. Hudebni rozhledy, roč. 21, 1968, č. 6, s. 152-153.

PEDUZZI, Lubomír. Pavel Haas. Čtyři písně na slova čínské poezie. Opus musicum, roč. 20, 1988, č. 6, s. 30-32.

PEDUZZI, Lubomír. Pavel Haas: Život a dilo skladatele. Brno: Muzejní a vlastivědná společnost v Brně, 1993.

PEDUZZI, Lubomír. Falešné problémy Haasových Čtyř písní. Hudebni věda, roč. 35, 1998, č. 3, s. 293-296.

PEDUZZI, Lubomír. O hudběv terezinském ghettu. Soubor kritických statí. Brno: Barrister \& Principal, 1999.

PIVODA, Ondřej. Nedokončené operní náčrty a neuskutečněné operní plány Pavla Haase. Opus musicum, roč. 50, 2018, č. 6, s. 64-80.

SCHULTZ, Ingo (ed.). Viktor Ullmann. 26 Kritiken über musikalische Veranstaltungen in Theresienstadt, mit einem Geleitwort von Thomas Mandl. Neumünster: Bockel Verlag, 1993.

SEDLÁČKOVÁ, Pavlína. Čtyř písně na slova činské poezie: Výpověd’ terezinského vězně. Bakalářská diplomová práce, Brno: Masarykova univerzita, Filozofická fakulta, 2011.

SPURNÝ, Lubomír. Pavel Haas: Janaček's Most Talented Student. Muzikološki zbornik, roč. 51, 2015 , č. 2, s. 119-125.

ŠTĚDROŇ, Bohumír. Česká hudba za nesvobody. Musikologie, 2, 1949, s. 106-146.

UTITZ, Emil. Psychologie života v terezinském koncentračním táboře. Praha: Dělnické nakladatelství, 1948. 